


\title{
Use of international legal assistance during the pre-trial investigation of corruption crimes in the sphere of official and professional activities
}

\author{
DOI: https://doi.org/10.46398/cuestpol.3969.10
}

\author{
Shevchyshen Artem * \\ Myrovska Anna ** \\ Antoshchuk Andrey *** \\ Sakovskyi Andrii **** \\ Piaskovskyi Vadym *****
}

\section{Abstract}

Based on the provisions of criminal procedure theory and criminology, the problems of international legal assistance are revealed during the pre-trial investigation for crimes of corruption in the field of official and professional activities. Special attention is paid to identifying the details of evidential activities in criminal proceedings for offences related to the provision of public services during a special pre-trial investigation (in absentia). The methodological basis of the article is a set of general and special scientific methods of legal cognition. In particular, the concept of pre-trial special investigation is formulated, its functional purpose is defined, characteristics of the carrying out of separate investigative actions (search) during the special pre-trial investigation for corruption offences. Attention is paid to issues of international cooperation to identify and search for assets in these criminal proceedings. Other problems are revealed in the use of international legal assistance to obtain evidence during the investigation of these crimes. It

* Doctor of legal sciences, docent, Head of the Service Crimes Investigation Department of the Corruption Crimes Investigation Department of the Main Investigation Department of the National Police of Ukraine, Kyiv, Ukraine. ORCID ID: https://orcid.org/oooo-ooo2-1342-6639. Email: Shevchishen@ police.gov.ua

** Candidate of legal sciences, Associate Professor, Professor at the Department of Criminalistics and forensic medicine, National Academy of Internal Affairs, Kyiv, Ukraine. ORCID ID: https://orcid. org/oooo-0o01-5714-1873. Email: a.mirovskaya@ukr.net

*** Candidate of legal sciences, Associate Professor at the Department of Criminalistics and forensic medicine, National Academy of Internal Affairs, Kyiv, Ukraine. ORCID ID: https://orcid.org/oooooo02-5088-4372. Email: antoshchuk2015@mail.com

**** Candidate of legal sciences, Associate Professor, Director of the educational and research institute No. 2, National Academy of Internal Affairs, Kyiv, Ukraine. ORCID ID: https://orcid.org/oooo-00o3o762-859X. Email: svb_knuvs@ukr.net

***** Candidate of legal sciences, Associate Professor, Professor of Department of Criminalistics and Forensic Medicine of National Academy of Internal Affairs, Kyiv, Ukraine. ORCID ID: https://orcid. org/oooo-0oo1-7954-1018. Email: pwwadd@gmail.com 
is concluded that a problem that arises during international cooperation during the preliminary investigation is the uncertainty in international rules on the provision of mutual legal assistance.

Keywords: corruption crimes; official and professional activities; pre-trial investigation; special pre-trial investigation; international legal assistance.

\section{Utilización de la asistencia jurídica internacional durante la instrucción de los delitos de corrupción en el ámbito de las actividades oficiales y profesionales}

\section{Resumen}

Con base en lo establecido en la teoría procesal penal y criminología se revelan los problemas de la asistencia jurídica internacional durante la investigación previa al juicio por delitos de corrupción en el ámbito de las actividades oficiales y profesionales. Se presta especial atención a identificar los detalles de las actividades probatorias en los procesos penales por delitos relacionados con la prestación de servicios públicos durante una instrucción especial previa al juicio (in absentia). La base metodológica del artículo es un conjunto de métodos científicos generales y especiales de cognición jurídica. En particular, se formula el concepto de instrucción especial previa al juicio, se define su propósito funcional, características de la realización de acciones de investigación (allanamiento) separadas durante la instrucción especial previa al juicio por delitos de corrupción. Se presta atención a los temas de cooperación internacional con el fin de identificar y buscar activos en estos procesos penales. Se revelan otros problemas de la utilización de la asistencia jurídica internacional para obtener pruebas durante la investigación de estos delitos. Se concluye que un problema que surge durante la cooperación internacional durante la investigación preliminar es la incertidumbre en las normas internacionales sobre la prestación de asistencia judicial recíproca.

Palabras clave: delitos de corrupción; actividades oficiales y profesionales; instrucción previa al juicio; instrucción especial previa al juicio; asistencia legal internacional. 
Shevchyshen Artem, Myrovska Anna, Antoshchuk Andrey, Sakovskyi Andrii y Piaskovskyi Vadym

Use of international legal assistance during the pre-trial investigation of corruption crimes in the sphere of official and professional activities

\section{Introduction}

The development of civil society is impossible without the state performing its functions in the fight against crime (Larkin, 2020). In this case, the implementation of the tasks of criminal proceedings depends primarily on proving the facts and circumstances that are the subject of proof in a particular criminal proceeding, including corruption offenses in the sphere of official activity and professional activity (Sukhachova, 2020).

At the same time, the results of the material analysis of the practice of crimes investigation show that one of the main drawbacks that negatively affect the investigation of facts and circumstances of corruption, as well as the resolution of criminal cases of this category, is the inadequate organization of international legal assistance. Theoretical and practical nature. These circumstances indicate the relevance of this issue and the timeliness of recourse to its study.

It should be noted that in recent decades at the global, continental, and regional levels, the issue of establishing effective cooperation between law enforcement agencies in different countries in detecting, investigating and preventing the most socially dangerous crimes is given much attention (Shevchishen, 2017). The UN Convention against Corruption of 31.10.2001 (United Nations Convention against Corruption, 2003) is an international legal act that definitively establishes the status of corruption crimes that globally threaten the normal development of state and social institutions in all countries of the world.

A clear example of the reality of such a threat is the events of 20132014 in Ukraine when one of the key factors influencing the mass protests against the ex-government was large-scale corruption, which affected the highest levels of government, which undermined the defense capabilities of our state. Damage to national security and law enforcement agencies, which ultimately contributed to external aggression against Ukraine and the temporary occupation of a part of its territory. The adoption of this Convention is the result of the gradual realization and recognition that corruption among senior officials in the state is often a tool used by organized crime to achieve its goals, which in some cases becomes international and therefore requires coordinated action by all states to effectively fight it. Therefore, it is urgent to form a legal framework that will serve as an appropriate basis for effective counteraction to the expansion of scope and forms of organized crime through corruption, its impact on democratic institutions in each country, distortions in the economy, mistakes in public administration and harming the moral climate of society (Inter-American Convention against Corruption, 1996).

Ukraine is an active participant in the development of the system of international legal acts, which cover all areas of cooperation between law 
enforcement agencies of different countries in the field of criminal justice, including the stage of pre-trial investigation. At the same time, society and the state must guarantee the protection of human and civil rights and compliance with the standards established by the Convention for the Protection of Human Rights and Fundamental Freedoms (Balobanova, 2020).

In fulfillment of international obligations, the Government and the Parliament of Ukraine have carried out a significant amount of work on the formation of the regulatory framework for international cooperation in criminal proceedings. In this context, special attention should be paid to the radical expansion of the normative provisions of Section IX of the Criminal Procedure Code of Ukraine in 2012 of the legal regulation of the procedure to be followed for international cooperation in criminal proceedings, extradition of persons who have committed criminal offenses, transfer of criminal proceedings (cases), recognition and execution of sentences of courts of foreign states and transfer of convicted persons. As rightly noted on this issue P.P. Minka and A.V. Khridochkin, in the Criminal Procedure Code of Ukraine of 1960 the provisions of Article 31 cannot be considered as providing proper and unambiguous regulation of international cooperation in criminal proceedings, so the novelties of Chapter IX of the Criminal Procedure Code of Ukraine in 2012 deserve only positive assessment (Minka and Khridochkin, 2013).

\section{Methodology of the study}

The methodological basis of the scientific article is a set of general scientific and special methods of cognition.

The dialectical method provided for the consideration of criminal procedural activities of pre-trial investigation bodies and other subjects during international legal assistance in the investigation of crimes in the sphere of official and professional activities.

The sociological method allowed to identify problematic issues that need to be addressed to improve the efficiency of the investigation of this category of crimes, and the statistical method provided a generalization of the results of the study of materials of criminal proceedings.

The system-structural method was used to determine the content of international cooperation, request for international legal assistance in criminal proceedings on corruption crimes, to clarify the specifics of obtaining evidence and their use in criminal proceedings on crimes of this category, and to clarify the procedure for obtaining evidence of corruption crimes during a special pre-trial investigation (in absentia). 
Shevchyshen Artem, Myrovska Anna, Antoshchuk Andrey, Sakovskyi Andrii y Piaskovskyi Vadym

Methods of analysis, synthesis, abstraction, forecasting, and formallogical provided the formulation of intermediate conclusions in the article, practical recommendations for improving international legal assistance in these crimes, proposals to improve the productivity of criminal proceedings for evidence of corruption.

\section{Analysis of recent research}

Issues of international cooperation in criminal proceedings were the subject of active research by R.M. Valeeva (Valeev, 1976), O.G. Vinogradova (Vinogradova, 2000), S.M. Vykhryst (Vykhryst, 2003), T.S. Gavrysh (Gavrysh, 2004), V.V. Zueva (Zuev, 2015), A.G. Kalugina and V.D. Shinkevich (Kalugin and Shinkevich, 2006), O.I. Lezhenina (Lezhenina, 2004), I.V. Leshukova (Leshukova, 2004), M.I. Pashkovsky (Pashkovsky, 2003), O.I. Sukhachova (Sukhachova, 2020), O.M. Tolochka (Tolochko, 2003), and many other scientists. In particular, the issues of the concept, principles, forms and main directions of international cooperation in criminal proceedings, grounds and procedural order of international legal assistance, the order of resolving issues of different legal regulation of certain procedural actions in criminal procedural legislation of some states and its impact on recognition evidence obtained during international legal assistance is admissible in criminal proceedings, etc. It should be recognized that the work on these issues will significantly influence the formation of modern criminal procedure legislation of Ukraine and the practice of providing international legal assistance in criminal proceedings.

\section{Results and discussion}

First of all, it should be noted that the current scientific achievements contain almost no coverage of the use of international legal assistance in the pre-trial investigation of corruption crimes in the field of official and professional activities. Also, the relevance of these issues arises from the analysis of the state of international cooperation in criminal proceedings, set out in Conclusion № (2007) 1 of the Advisory Council of European Prosecutors "Ways to improve international cooperation in criminal justice", adopted by the European Commission on Justice Efficiency o7 Council of Europe.12. (Opinion № (2007) 1 of the Advisory Council of European Prosecutors), and the content of multilateral and bilateral agreements on international cooperation in criminal proceedings. In particular, paragraphs $15,16,18$ of this Opinion emphasize the numerous obstacles that hinder the necessary development of mutual legal assistance in criminal proceedings and cause the excessive length of current procedures of international cooperation, in particular, it is stated that: 
- European mechanisms of legal cooperation do not always meet modern challenges and requirements.

- the process of requesting assistance may be detrimental to the cooperation process (for example, they may be too concise or overloaded with unnecessary details, unsigned, unsubstantiated, incorrectly translated, inaccurate, inappropriate, etc.). This shortcoming is mainly due to lack of training, the complexity of procedures, and lack of allocated resources.

- requests are too often transmitted only through diplomatic channels, although the European Convention on Mutual Assistance in Criminal Matters (ETS № 30) (European Convention on Mutual Assistance in Criminal Matters, 1959) allows direct links between the competent judicial authorities for the submission and execution of requests, the lack of information (specific data on the competent authorities) often forces them to act through central authorities, moreover, the simultaneous use of different channels of communication hinders the smooth implementation of the cooperation procedure.

- the increase in the number of requests for mutual assistance is a factor that also paralyzes the current procedures because sometimes the requested authorities are overwhelmed by the execution of requests concerning minor cases.

- when fulfilling requests, the lack of a common European culture of cooperation in court cases and some resistance lead to the fact that the procedures of international cooperation are systematically replaced by internal procedures (Shevchishen, 2017).

It is also noted that, in addition to the above, much greater difficulties arise due to differences between legal systems. In particular, as a key issue, along with double criminal responsibility (ne bis in idem principle) and different powers of the requesting authority, there are different means of obtaining evidence and the existing system of judicial decisions in some states in absentia. They are key examples of concepts and procedures that depend on international coherence, which would facilitate cooperation between different systems. Last but not least is the delay in fulfilling the request for legal aid without any objective reasons due to improper performance of professional duties by the executors of the request without any expected legal consequences (Conclusion 2007 (2007) 1 of the Advisory Council of European Prosecutors, 2007).

In this regard, we note that despite the strong international support for the activities of the Specialized Anti-Corruption Prosecutor's Office and the National Anti-Corruption Bureau of Ukraine with delays in responding to requests for legal assistance in criminal proceedings for corruption in the field of official and professional activities, they also experienced problems. 
Shevchyshen Artem, Myrovska Anna, Antoshchuk Andrey, Sakovskyi Andrii y Piaskovskyi Vadym

N. Kholodnytsky notes that, for example, the pre-trial investigation into the report of suspicion to the People's Deputy of Ukraine M.V. Martynenko lasted more than a year since more than ten international orders were executed in eight countries in criminal proceedings. Some assignments sent in March 2016 were executed and received responses in January 2017. The last order was received on April 18, 2017. After that, the prosecutor agreed to report the suspicion of M.V. Martynenko (Kholodnytsky Told About The Procedure Of Martynenko's Case, 2016).

Similar long-term fulfillment of requests for international legal assistance during the pre-trial investigation in criminal proceedings on corruption offenses in the sphere of official and professional activity was established in $96 \%$ of investigated cases of such requests in criminal proceedings investigated by the pre-trial investigation bodies of the National Police of Ukraine (Shevchishen, 2019). And, unfortunately, the current international legal acts do not have clear instructions on the terms of execution of international requests for legal assistance in criminal proceedings. N. Kholodnytsky rightly emphasized this (Kholodnytsky Told About The Procedure Of Martynenko's Case, 2016).

Many years of experience in the execution of international orders show that it is insufficient to define in an international agreement that a request for international legal assistance is subject to immediate execution because such urgency is treated as the immediate beginning of international order and not as the fastest execution.

In this case, it should be noted that the indication of the urgency of the request is not a standard component of the normatively defined procedure for the execution of international orders in the relevant treaties concluded by Ukraine. Given the provisions of paragraph 3 part 1 of Article 280 of the Criminal Procedure Code of Ukraine, which provides the possibility of suspending the pre-trial investigation after notifying a person of suspicion if there is a need to perform procedural actions within international cooperation, the legislator may consider international warrants (Criminal Procedure Code Of Ukraine, 2012). In the context of maintaining the pretrial investigation deadlines set out in Article 219 of the Criminal Procedure Code of Ukraine, this has indeed been done.

However, this has not happened in the aspect of evidence in criminal proceedings in which international legal assistance is sought. The implementation of procedural actions abroad is aimed at obtaining evidence, without which the further movement of the pre-trial investigation is problematic, and in some cases impossible. Due to this, the pre-trial investigation is suspended by paragraph 3 part 1 of Article 280 of the Criminal Procedure Code of Ukraine (Criminal Procedure Code Of Ukraine, 2012). The longer the period during which domestic investigators do not take legal action, the greater the risks of losing sources of evidence that 
we do not know about but may learn from materials provided by foreign competent authorities. Therefore, the problem of delays in the execution of requests for international legal assistance is real and has a negative impact on the results of evidence in criminal proceedings, and in the case of a person identified as a suspect, as well as in cases where the suspicion was not announced.

At first glance, it seems optimal in this situation to amend the existing conventions and bilateral agreements in the context of setting deadlines for requests for international legal assistance in criminal proceedings. However, given the complex and lengthy procedure of initiating, preparing and approving, organizing the signing and ratification of international regulations, the entry into force of the relevant changes will take not just years but decades. For example, the signing and ratification of the Additional Protocol to the European Convention on Mutual Assistance in Criminal Matters by 35 states took 23 years (List of signatures and ratifications of the Additional Protocol to the European Convention on Mutual Legal Assistance in Criminal Matters, 1978).

The problem with the terms of execution of international legal orders in criminal proceedings is complicated by the fact that there are no uniform approaches to the standardization of this issue in the criminal procedure legislation of foreign states. For example, paragraph 1 of $\S 91 \mathrm{~g}$ of the Law of the Federal Republic of Germany on International Legal Assistance in Criminal Matters (Gesetz über die internationale Rechtshilfe in Strafsachen, 1982) of 23 December 1982 (BGBL. 1982 IS.2071) stipulates that international legal assistance must be provided. Within 30 days of receipt of a request from the competent authority, and in paragraph 2 §91g, that such period shall not exceed 90 days. In this case, in accordance with the regulations of paragraph $3 \S 91 \mathrm{~g}$, the terms of international legal assistance provided for in paragraphs 1, 2 §91g of this Law of the Federal Republic of Germany may be reduced at the request of the competent authority of a foreign state, and in accordance with paragraph $4 \$ 91 \mathrm{~g}$, if this cannot be done, the competent authority of the requesting State must be notified (Gesetz über die internationale Rechtshilfe in Strafsachen BGBL, 1982).

A similar approach to determining the terms of execution of a request for international legal assistance is present in Part 2 of Article 558 of the Criminal Procedure Code of Ukraine (Criminal Procedure Code Of Ukraine, 2012). According to Part 2 of Article 495 of the Criminal Procedure Code of the Republic of Belarus, the term of execution of appeals within the framework of providing international legal assistance to the bodies conducting the proceedings is determined by the Prosecutor General of the Republic of Belarus or his deputies (Code Of Criminal Procedure Of The Republic Of Belarus, 1999). 
These regulations generally reflect the typical approaches to the regulation in the criminal procedure legislation of foreign countries on the timing of international orders, namely, by clearly defining the timing of requests for international legal assistance in criminal matters with the possibility of adjusting them on request the competent authority of another state; - establishing the competence of the Prosecutor General or his deputy to determine in his decision the deadline for applying for international order (Shevchyshen, 2017).

The terms of execution of international orders may also be affected by the provisions of the criminal procedure legislation of certain countries, according to which the execution of certain procedural actions carried out at the request of the competent authority of another state may be challenged in court. seizure of property, bank accounts, etc. Domestic bodies of pretrial investigation are aware of many delayed cases due to this the execution of international orders (Sytnyk, 2016).

Part 2 of Article 552 of the Criminal Procedure Code of Ukraine contains requirements for a request for international legal assistance, the elements of which are: 1) the name of the requesting authority and the competent authority of the requested party; 2) reference to the relevant international agreement or to the observance of the principle of reciprocity; 3) the name of the criminal proceedings in respect of which international legal assistance is requested; 4) a brief description of the criminal offense that is the subject of criminal proceedings and its legal qualification; 5) information on the reported suspicion, accusation with the full text of the relevant articles of the Criminal Code of Ukraine; 6) information about the person concerned, in particular his / her name, procedural status, place of residence or stay, citizenship, other information that may facilitate the execution of the request, as well as the connection of this person with the subject of criminal proceedings; 7) a clear list of requested procedural actions and justification of their connection with the subject of criminal proceedings; 8) information on persons whose presence is considered necessary during the performance of procedural actions, and substantiation of this necessity; 9) other information that may facilitate the execution of the request or provided by an international agreement or requirement of the competent authority of the requested party (Criminal Procedure Code Of Ukraine, 2012).

The Criminal Procedure Code of Ukraine does not provide for the possibility of requesting the execution of an international order within a certain period. However, does this mean its inadmissibility and inadmissibility? We believe not. First, the wording of the legislator in part 2 of Article 552 of the Criminal Procedure Code of Ukraine prescribing that the information contained therein must be in the request for international legal assistance does not mean that their list is exclusive, i.e. cannot be expanded and similar restrictive prescriptions are absent in international legal acts on 
the issue under consideration (Criminal Procedure Code Of Ukraine, 2012). Secondly, the expansion of the content of the request for international legal assistance is permissible given the principles of reciprocity and courtesy, which are inherent in international relations (Uzunova, 2008). Therefore, we believe that it is not just permissible, but appropriate in requests for international legal assistance to prevent delays in fulfilling an international order to ask the requested party to provide such assistance within a certain timeframe. If such terms are defined in the criminal procedural legislation of the requested party, then the request must be guided by them, and if such terms are not specified, then - the practice of procedural actions by investigators in our state.

In addition to this problem, the in-absentia regime can significantly complicate the collection of evidence using international legal assistance measures during a special pre-trial investigation. This issue is not unreasonably addressed in the above-mentioned Opinion № (2007) 1 of the Advisory Council of European Prosecutors "Ways to Improve International Cooperation in Criminal Justice", adopted by the European Commission for the Efficiency of Justice of the Council of Europe on 07.12.2007 (Council Of European Prosecutors, 2007).

It should be noted that a special pre-trial investigation is designed to ensure a speedy, complete and impartial investigation and further trial by gathering evidence in criminal proceedings in the face of opposition to the investigation by the suspect in the form of evasion of criminal liability by the investigator a suspect for protection through the exercise of his procedural rights during such a pre-trial investigation by a defense counsel. Only in cases of impossibility to search for and extradite a suspect, in particular, due to the refusal to apply the procedure of search and extradition by the country where the suspect is, according to the pre-trial investigation, it is advisable to use a special pre-trial investigation (Shevchishen, 2019).

The problem of gathering evidence with the use of international legal assistance during the pre-trial investigation of corruption crimes in the field of official and professional activities is that not all states provide for the possibility of criminal proceedings in absentia. In the Romano-Germanic (continental) and Anglo-American (common law), systems historically formed a different vision of the peculiarities of implementation, the socalled right of confrontation. As noted by M.I. Pashkovsky, Article $6 \S 3$ (d) of the Convention for the Protection of Human Rights and Fundamental Freedoms provides for the right of a person accused of a criminal offense to question witnesses or to examine them, the same conditions as the witnesses who testify against it. This right of the accused (suspect, defendant) in the Western European legal tradition is defined as the right of confrontation. Close in meaning and content is the institution of cross-examination in the judiciary of common law countries. The right of confrontation is one of the 
Shevchyshen Artem, Myrovska Anna, Antoshchuk Andrey, Sakovskyi Andrii y Piaskovskyi Vadym

expressions of the principle of equality of arms, which follows from the principle of a fair trial (Pashkovsky, 2003).

Different understandings of the content and permissible forms of exercising this right in different states may lead to the refusal to comply with requests for international assistance through procedural actions. At one time, the United States denied Italy the execution of its consul's letter in Denver to the United States for questioning witnesses residing in the United States, Francesco and Elisabetta Macri, and Maria and Franco Macri in the case of the murder of an Italian citizen - Francesco Archina. Francesco Archina was charged with murder in Denver. A Denver court found that Francesco Archina was in a state of insanity at the time of the murder, so he was sent to Pueblo State Hospital for treatment. After some time, the American authorities deported Francesco Archina to his homeland - Italy. Based on the principle of nationality, Francesco Archina was prosecuted by an Italian investigating judge for a murder committed in the United States of America. An Italian investigation has called for the questioning of 25 witnesses in the United States. The reason for the refusal to provide legal aid was the contradiction of the Italian authorities' request for Amendment VI of the United States Bill of Rights, because the accused, who was already in Italy, was deprived of the right to confrontation, i.e. cross-examination of witnesses against him (Mueller GOW and Wise, 1965; Pashkovsky, 2003).

Analysis of foreign literature shows that the implementation of criminal proceedings in absentia has repeatedly influenced the decision to refuse the extradition of perpetrators (Ruggeri, 2017; Šepec, 2015). Although the domestic investigative practice is not aware of cases of refusal to provide international legal assistance in conducting procedural actions during a special pre-trial investigation, it should be borne in mind that the potential risks of obtaining such a refusal in states whose criminal procedure legislation does not provide for criminal proceedings in absentia.

This is especially true of requests for the extradition of persons who have committed a criminal offense. The probability of refusal is significantly increased in situations where such persons have been convicted using special court procedures. Therefore, we propose to consider the regime of special pre-trial investigation as an exclusive form of pre-trial investigation, the decision on the application of which should be made as a result of exhaustion of opportunities for interstate and/or international search of the suspect and his extradition.

In the context of the researched issues, the issue of international cooperation in order to identify and search for assets in the framework of criminal proceedings on corruption crimes in the field of official and professional activities needs special attention. In particular, in accordance with the Criminal Procedure Code of Ukraine (Article 568), based on a request for international legal assistance, the relevant bodies of Ukraine 
carry out procedural actions provided by this Code, as well as other actions provided by special law to identify and seize property, money criminal means, as well as property belonging to suspects, accused or convicted persons (Criminal Procedure Code Of Ukraine, 2012).

A special law, in this case, is the Law of Ukraine "On the National Agency of Ukraine for Detection, Search and Management of Assets Obtained from Corruption and Other Crimes". In accordance with the international agreements of Ukraine, the National Agency, on the principle of reciprocity or its initiative, carries out international cooperation with the relevant authorities of foreign states in the exchange of information on issues related to detection, search and asset management.

It carries out international cooperation at the request of the relevant body of a foreign state. In order to perform its tasks, the national agency has the right to receive process and exchange information about individuals and legal entities in the manner prescribed by international treaties and legislation of Ukraine. The National Agency also accepts for consideration and executes the request received from the requesting party by electronic, facsimile, or other means of communication, if it is provided by international agreements of Ukraine or is carried out based on the principle of reciprocity. Refusal or postponement of the request for international cooperation in the field of detection and tracing of assets is carried out only based on international agreements to which Ukraine is a party (National Agency of Ukraine For Detection, 2015).

International cooperation in criminal proceedings on corruption offenses in the sphere of official and professional activities also takes place using Interpol's capabilities. In Ukraine, it is the main body for the registration of transnational crimes and those who committed them, and the main coordinator of the international search for persons who have committed criminal offenses. Among other things, pre-trial investigation bodies of Ukraine in the framework of international cooperation may use a database of persons, facts, objects, and documents accumulated based on information obtained in the process of international police cooperation.

When organizing an international search, Interpol channels should be guided by generally accepted principles and norms of international law, comprehensive and bilateral international treaties of Ukraine, the Constitution of Ukraine, laws, the Interpol Charter, binding decisions of the Interpol General Assembly, regulations of the Ministry of Internal Affairs of Ukraine, etc. 
Shevchyshen Artem, Myrovska Anna, Antoshchuk Andrey, Sakovskyi Andrii y Piaskovskyi Vadym

194

Use of international legal assistance during the pre-trial investigation of corruption crimes in the sphere of official and professional activities

\section{Conclusions}

The problems investigated in the scientific article prompted them to comprehend and develop measures to avoid and minimize them during the pre-trial investigation of corruption crimes in the field of official and professional activities. Based on this, we made the following conclusions:

1. A problem that arises during international cooperation during the pre-trial investigation is the uncertainty in international regulations on the provision of mutual legal assistance in criminal proceedings, the timing of the execution of international order. This, according to investigative practice, negatively affects the effectiveness of pre-trial investigation of crimes in the field of official and professional activities, significantly reduces the pace of investigative (investigative), covert investigative (investigative), and other procedural actions. Because making changes and additions to set deadlines for international assignments is a long process, we recommend that such requests be sure to ask the requested party to execute it within a certain period based on reciprocity, justifying the importance of this.

2. When applying for international legal assistance during a special pre-trial investigation of corruption offenses, it should be borne in mind that in some countries the law does not provide for the conduct of criminal proceedings in absentia. There are risks of refusing to comply with a request for international legal assistance in criminal proceedings. Therefore, it is recommended to seek the assistance of law enforcement agencies of such states before making a procedural decision to conduct a special pre-trial investigation.

3. In international cooperation in criminal proceedings on corruption offenses in the field of official and professional activities, it is advisable to actively use the capabilities of Interpol, which in Ukraine is the main body for transnational crimes and criminals and the main coordinator of international investigations.

\section{Bibliographic References}

ABOUTTHENATIONAL AGENCY OF UKRAINE FOR DETECTION, SEARCH AND MANAGEMENT OF ASSETS OBTAINED FROM CORRUPTION AND OTHER CRIMES. 2015. On November 10. Available online. In: http://zakon3.rada.gov.ua/laws/show/772-19. Consultation date: 09/09/2020. 
BALOBANOVA, Dariia; GORBACHOVA, Iryna; OTSYATSYA, Anastasiia; DMYTRUK, Mykhailo; KHYLCHENKO, Anastasiia. 2020. "Dynamics of the implementation of the protective role in the conduct of crimes: the practice of the Convention for the Protection of Human Rights and Fundamental Freedoms" In: CUESTIONES POLITICAS. Vol. 38, No. Especial (2da parte) p. 427.

CODE OF CRIMINAL PROCEDURE OF THE REPUBLIC OF BELARUS. 1999. July 16. No 295-C. Available online. In: http://etalonline. by/?type=text\&regnum $=$ HK9900295\#load_text_none_1_.57. Consultation date: 09/09/2020.

CONCLUSION NO. 1. 2007. OF THE ADVISORY COUNCIL OF EUROPEAN PROSECUTORS "Waysto ImproveInternationalCooperationin Criminal Justice”. 2007. 07 December. Available online. In: https://www.viaduk. net/clients/vsu/vsu.nsf/7864c99c46598282c2257b4c0037c014/ f8co93ad5cb7148bc2257d8doo2488ao/\$FILE/\%Do\%92\%Do\%B8\% D1\%81\%Do\%BD\%Do\%BE\%Do\%B2\%Do\%BE\%Do\%BA\%20\%E2\% 84\% 96\%201(2007).pdf. Consultation date: 09/09/2020.

CRIMINAL PROCEDURE CODE OF UKRAINE. 2012. On April 13. Available online. In: https://zakon.rada.gov.ua/laws/show/4651-17. Consultation date: 09/09/2020.

EUROPEAN CONVENTION ON MUTUAL ASSISTANCE IN CRIMINAL MATTERS. 1959. 20 April. Available online. In: http://zakon3.rada.gov. ua/laws/show/995_036/print. Consultation date: 09/09/2020.

GAVRYSH, Tetiana. 2004. Problems of admissibility of the proofs received during reception of the international legal aid in criminal cases: dissertation of the candidate of legal sciences. Kharkiv, Ukraine.

GESETZ ÜBER DIE INTERNATIONALE RECHTSHILFE IN STRAFSACHEN BGBL. 1982. On December 31. No 2071. Available online. In: https://www.bgbl.de/xaver/bgbl/start.xav?start=//*\%5B@attr_ id=\%27bgbl182s2071.pdf $\% 27 \% 5 \mathrm{D \#} \_$bgbl_ $\% 2 \mathrm{~F} \% 2 \mathrm{~F} * \% 5 \mathrm{~B} \% 40$ attr_ id\%3D\%27bgbl182s2071.pdf\%27\%5 $\mathrm{D}_{\text {__ }}$ 1618155817018. Consultation date: 09/09/2020.

INTER-AMERICAN CONVENTION AGAINST CORRUPTION. 1996. On March 29. Available online. In: http://zakon3.rada.gov.ua/laws/ show/998_089. Consultation date: 09/09/2020.

KALUGIN, A; SHINKEVICH, Dmytro. 2006. International cooperation in the field of criminal proceedings: theory and practice: a textbook Krasnoyarsk. Russia. 
Shevchyshen Artem, Myrovska Anna, Antoshchuk Andrey, Sakovskyi Andrii y Piaskovskyi Vadym

196

Use of international legal assistance during the pre-trial investigation of corruption crimes in the sphere of official and professional activities

KHOLODNYTSKY TOLD ABOUT THE CASES OF MARTYNENKO, ONYSCHENKO AND AVAKOV. 2016. On October 17. In: Ukrainian Pravda. Online article. Available online. In: https://www.pravda.com. ua/news/2016/10/17/7123878. Consultation date: 09/09/2020.

LARKIN, Mikhail; BIRYUKOVA, Alina; MAKARENKO, Tamara; IVANOVA, Natalia; FEDCHYNIAK. 2020. "Typical Mistakes during Investigation of Crimes Committed by Youth Informal Groups Members" In: CUESTIONES POLÍTICAS. Vol. 38. No Especial., p. 396.

LESHUKOVA, Iryna. 2004. Procedural features of the international cooperation of bodies of internal affairs of Ukraine at investigation of crimes: dissertation of the candidate of legal sciences. Kharkiv, Ukraine.

LEZHENINA, Olga 2004. Organizational and legal bases of participation of bodies of internal affairs of Ukraine in the international law enforcement activity: dissertation of the candidate of legal sciences. Kharkiv, Ukraine.

LIST OF SIGNATURES AND RATIFICATIONS OF THE ADDITIONAL PROTOCOL TO THE EUROPEAN CONVENTION ON MUTUAL ASSISTANCE INCRIMINALMATTERS. 1978. (ETSNo.99)(Strasbourg, 17 March 1978). Available online. In: https://zakon.rada.gov.ua/laws/ show/994_422. Consultation date: 09/09/2020.

MINKA, Pavlo; KHRIDOCHKIN, Andriy. 2013. "Characteristics of forms of international cooperation in the fight against crime in the context of the problem of adaptation of domestic legislation to the legislation of the European Union" In: Law and society. No 3, p. 177.

MUELLER, G.O.W., WISE, E.M. 1965. Mueller International criminal law. Rothman. NewYork, London.

PASHKOVSKY, Mykolay. 2003. Features of proof in criminal cases related to the provision of international legal assistance: dissertation of the candidate of legal sciences. Kiev, Ukraine.

RUGGERI, Stefano. 2017. Audi alteram partem in criminal proceedings: towards a participatory understanding of criminal justice in Europe and Latin America. Available online. In: https://www.springer.com/gp/ book/9783319545721. Consultation date: 09/09/2020.

ŠEPEC, Miha. 2015. International Criminal Cooperation Extradition and Surrender Procedures - Modern Trends and Problems. VARSTVOSLOVJE, Journal of Criminal Justice and Security. No. 2. P. 278. Available online. In: https://www.fvv.um.si/rv/arhiv/2013-2/o9_ Sepec-E.html. Consultation date: 09/09/2020. 
SHEVCHISHEN, Artem. 2017. "Use of international legal assistance to gather evidence during a special pre-trial investigation” In: Visegrad Journal on Human Rights. No 1, p. 205.

SHEVCHYSHEN, Artem. 2019. Problems of proof by the prosecution in the pretrial investigation of corruption crimes in the sphere of official activity and professional activity related to the provision of public services: dissertation of the candidate of legal sciences. Kiev, Ukraine.

SUKHACHOVA, Iryna. 2020. "The concept and content of evidence by the prosecutor in the investigation of corruption crimes in the field of official activities and professional activities related to the provision of public services" In: HERALD LUHANSK STATE UNIVERSITY OF INTERNAL AFFAIRS AND THEM. E.O. DIDORENKO. Vol. 4 (92). pp. 188-189.

SYTNYK, Artem. 2016. No one will be able to bring conflict into the relationship between the National Anti-Corruption Bureau of Ukraine and the Specialized Anti-Corruption Prosecutor's Office. In: Online article. Available online. In: https://nabu.gov.ua/novyny/artem-sytnyknikomu-ne-vdastsya-vnesty-konflikt-u-vzayemyny-nabu-i-sap. Consultation date: 09/09/2020.

TOLOCHKO, Oleg. 2013. "Humanization of the extradition procedure for persons who have committed criminal offenses" In: Bulletin of the National Academy of the Prosecutor's Office of Ukraine. No 2, p. 53.

UNITED NATIONS CONVENTION AGAINST CORRUPTION. 2003. 31 October. Available online. In: https://zakon.rada.gov.ua/laws/ show/995_c16. Consultation date: 09/09/2020.

UZUNOVA, Oksana. 2008. International legal agreements of Ukraine as a source of criminal procedure law: dissertation of the candidate of legal sciences. Zaporozhye, Ukraine.

VALEEV, Ruslan. 1976. Extradition of criminals in modern international law (some issues of theory and practice). Monograph. Kazan, Russia.

VINOGRADOVA, Oksana. 2000. International cooperation of Ukraine in the fight against crime (criminal procedure aspect): dissertation of the candidate of legal sciences. Kharkiv, Ukraine.

VYKHRYST, Sergiy 2003. Extradition of persons in the aspect of the ratio of international and national law: dissertation of the candidate of legal sciences. Kharkiv, Ukraine.

ZUEV, Volodymyr. 2015. Criminal procedural guarantees of the rights of the person at the international cooperation during criminal proceedings: dissertation of the candidate of legal sciences. Kharkiv, Ukraine. 
Vol. 39 N $^{\circ} 69$

Esta revista fue editada en formato digital y publicada en julio de 2021, por el Fondo Editorial Serbiluz, Universidad del Zulia. Maracaibo-Venezuela 